УДК 930.2 : [32-055.2 : 28] : 328 (44) «2007/2012»Ф. Фійон

DOI: https://doi.org/10.33782/eminak2020.2(30).421

\title{
МУСУЛЬМАНИ В УРЯДАХ ФРАНСУА ФІЙОНА
}

\author{
Богдана Сипко \\ Львівський національний університет імені Івана Франка (Львів, Україна) \\ e-mail: bogdanasypko@gmail.com \\ ORCID: https://orcid.org/0000-0002-3136-9340
}

\begin{abstract}
У статті, на основі офіційного державного друкованого органу, матеріалів виступів, інтерв'ю та публіцистичних творів французьких політиків, проаналізовано склад трьох урядів Франсуа Фійона (2007-2012) та простежено, яку роль у них відігравали мусульмани. Встановлено, що Ніколя Саркозі у цьому контексті залучав до уряду, насамперед, жінок, таким чином апелюючи не лише до сприяння «розмаїттю» у владі, а й до подолання недостатнього представлення другої статі у вищих ешелонах влади. Основний акцент зроблено на тому, як міністри та держсекретарі узгоджували свою ісламську ідентичність і вимоги світської держави.
\end{abstract}

Ключові слова: іслам, політики-мусульмани, уряд, Франція, Ніколя Саркозі

На території Французької республіки на початку XXI ст. мешкала найбільша ісламська умма (спільнота) Західної Європи. 3 огляду на чинну з 1872 р. заборону вносити у бланки переписів населення питання про віросповідання, точних цифр апріорі бути не може, однак, за підрахунками демографів, кількість мусульман у Франції коливається від 4 до 6 млн. осіб. Хоча спільнота виникла, насамперед, внаслідок імміграції (початково трудової, а з середини XX ст. і політичної), на зламі XX-XXI ст. у Республіці вже сформувалося т. зв. «друге» та «третє» покоління, тобто народжені у Франції особи, які отримали французьке громадянство, а, відтак, ставали повноправними суб'єктами громадсько-політичних відносин. Тому вважаємо, що аналіз участі мусульманської спільноти у політичному житті Франції має як наукову, так і суспільнополітичну актуальність, оскільки ЗМІ дуже часто обмежують питання ісламу на Заході терористичними актами та заворушеннями у т. зв. «складних передмістях»1.

До питання участі мусульманської спільноти у політичному житті Республіки вже зверталася Богдана Сипко, однак досі дослідниця обмежувалася періодом президентства Жака Ширака². 3 огляду на те, що за каденції Ніколя Саркозі (2007-2012) залучення мусульман до уряду стало цілеспрямованою державною політикою, покликаною проілюструвати «відкритість» до «різноманіття» Республіки, пропонуємо хронологічно продовжити цей аналіз. У цьому нам допомогли праці вчених, які працюють у ключі ґендерних (Марієтт Сіно ${ }^{3}$ Маянті Фернандо ${ }^{4}$ і постколоніальних

\footnotetext{
1 «Складна» міська зона - французькі квартали із високим рівнем злочинності. Цей термін офіційно вживався у 1995-2014 рр., у 2015 р. його замінили на «quartier prioritaire» (пріоритетний квартал).

${ }^{2}$ Сипко Б. Мусульманська спільнота у житті Французької республіки (1995-2007). Львів: Львівський національний університет імені Івана Франка, 2017. С. 133-150.

3 Sineau M. Les femmes et le pouvoir exécutif en France: de l'éxecution... à l'adoublement présidetiel. Recherches féministes. 2010. № 23 (1). P. 81-97.

${ }^{4}$ Fernando M. Exceptional citizens: Secular Muslim women and the politics of difference in France. Social Anthropology. 2009. № 14. P. 379-392.
} 
(Марі-Кармен Гарсіа5 ${ }^{5}$ Ізабелла Грайфендер6, Розелла Спіна7) студій. Якісною є й колективна монографія британських вчених «Президентство Саркозі. Знищення цвілі?»8. Однак, у жодному із перелічених досліджень питання мусульман у складі урядів 2007-2012 рр. окремо не розглядалося.

Відповідно, метою пропонованої статті $є$ проаналізувати, як були представлені особи ісламського віросповідання у трьох урядах Франсуа Фійона, з'ясувати політичні стратегії та світоглядні координати цих діячів, і прояснити, наскільки вдалими у контексті залучення мусульман були підходи шостого Президента П'ятої республіки. Для цього було використано архіви офіційного друкованого органу Франції Journal officiel de la République Française (далі - JORF) за 2007-2012 рр., стенограми виступів і інтерв'ю політиків-мусульман, доступні на урядовій інтернет-платформі Vie-publique.fr i публіцистичний твір політикині Фадели Амария.

Шостий Президент Франції Ніколя Саркозі був надзвичайно амбітною людиною, він не шукав авторитетів у минулому, а прагнув здійснити у державі глибинні перетворення. 5 червня 2008 р., відповідаючи на питання журналістів, чи надихається він прикладом Шарля де Голля (1958-1969), Президент відповів: «Я, ґолліст? Все не так просто. Генерал де Голль був великою людиною у червні 1940 р., тоді в травні 1958 р. У першому випадку він повернув нашу честь, у другому - дав Конституцію. А після? Які його результати? Що він саме робив? Чесно, пора завершити з легендою» 10.

Наважившись підважити ідеали голлізму, при цьому будучи політиком правого спрямування, Н. Саркозі мусів сформувати власну доктрину. I її елементи простежуються вже у передвиборному виступі у Безансоні 13 березня 2007 р. «Імміграція та національна ідентичність», в якому діяч не лише гарантував недоторканість основних республіканських постулатів, а й наголосив на своїх іммігрантських коренях і почав популяризувати тезу про «різноманіття» (diversité) ${ }^{11}$. Термін «різноманіття» поширився у політичному дискурсі Франції ще у часи Жака Ширака, особливо за прем'єрства соціаліста Ліонеля Жоспена (1997-2002), але використовувався в основному в контексті необхідності ширшого представлення жінок у владі12.

Ніколя Саркозі семантично розширив це поняття, включивши до нього не лише ґендерний, а й етнічний і релігійний аспекти, таким чином переходячи від чіткого дотримання асиміляційної політики, характерної для Франції ще з часів Другої імперії (1852-1870) до реверансів мультикультуралізму. 3 ініціативи Президента створили нове міністерство Імміграції, інтеграції, національної ідентичності та співрозвитку (2010 р. ліквідоване), здійснена спроба запровадити етнічну статистику (у листопаді 2007 р. відкинула Конституційна рада), у грудні 2008 р. запроваджено посаду

\footnotetext{
5 Garcia M.-C. Des feminismes aux prises avec l'intersectionnalité: le mouvement Ni Putes Ni Soumises et le Collectif féministe du Mouvement des Indigènes de la République. Recherches féministes. 2012. № 25 (1). P. 111-126.

${ }^{6}$ Greifeneder I. Analyse du discours sarkozien au sujet de l'immigration et de l'identité nationale. Wien: Universitat Wien, 2009. 148 p.

${ }^{7}$ Spina R. Enfants de harkis et enfants d'émigrés. Parcours croisés, identités à recoudre. Paris: Éditions Karthala, 2012. 256 p.

8 The Sarkozy Presidency. Breaking the Mould? / Ed. By G. Raymond. London: Palgrave Macmillan, 2013. $216 \mathrm{p}$.

${ }^{9}$ Amara F. Ni putes ni soumises. Paris: Éditions La Découverte, 2003. 156 p.

10 The Sarkozy Presidency. Breaking the Mould?... P. 15.

${ }^{11}$ Greifeneder I. Analyse du discours sarkozien... P. 115-121.

12 The Sarkozy Presidency. Breaking the Mould?... P. 130.
} 
Верховного комісара з питань різноманіття та рівності шансів (у липні 2012 р. Франсуа Олланд скасував посаду). Восени 2007 р. Ніколя Саркозі у період Рамадану взяв участь у святковій вечері - іфтарі, на чому окремо наголосив у виступі: «Мені здається, що я перший Президент Республіки, який прийшов у Велику Паризьку мечеть, щоби взяти участь в іфтарі. Навіть президент Думерг [Гастон Думерг (1924-1931)], який був лише на інавгурації, цього не зробив»13. А в 2010 р. глава уряду Франсуа Фійон урочисто відкривав мечеть в Аржентеї14, що свідчило не стільки про симпатії до ісламської умми, як чітку урядову лінію, оскільки в березні 2012 р. він назвав ритуальне вбивство тварин для виготовлення халяльного та кошерного м'яса негуманним рудиментом, що консолідувало французьких мусульман та іудеїв 15.

Для чого ж здійснювали ці заходи? Лаконічно на це запитання відповів Бернар Ґодар, радник з питань ісламу міністерства внутрішніх справ Франції у 19952007 рр.: «у нього [Ніколя Саркозі - Aвт.] були погляди «аля американський лібералізм»: для того, щоби я виграв голоси, потрібна підтримка спільноти» ${ }^{16}$. Саркозі хотів таким чином «притягнути» голоси осіб іммігрантського походження, у тому числі й мусульман, які традиційно підтримували партії лівого спрямування. Показово, що наприкінці президентської каденції, з цієї електоральної стратегії іронізували навіть французькі тижневики. Так, 14 березня 2012 р. журналісти Le Nouvel Observateur у статті «Подвійна гра Ніколя Саркозі щодо мусульман» відзначали: «Йдеться про 3,9 млн. виборців» ${ }^{17}$.

Ці ж тенденції, закономірно, відобразилися й у формуванні французьких урядів. Реалізовуючи концепт «різноманіття», Н. Саркозі взяв до уваги недостатню представленість у владі як жінок ${ }^{18}$, так і осіб іммігрантського походження, запропонувавши «комплексне» рішення. У першому уряді Франсуа Фійона (18 травня - 18 червня 2007) портфель міністра юстиції отримала речниця Ніколя Саркозі у передвиборній кампанії, Рашида Даті19. Згідно французького законодавства, після парламентських виборів обов'язково формується новий уряд. Тому до складу другого кабінету Ф. Фійона (19 червня 2007 - 13 листопада 2010) увійшли Фадела Амара (держсекретар з питань політики міста), Рама Яде (держсекретар з питань закордонних справ і прав людини), а Р. Даті зберегла свій портфель ${ }^{20}$. Цей уряд 12 разів частково змінював склад: так, 23 червня 2009 р. Р. Яде стала держсекретарем 3 питань спорту, Р. Даті покинула уряд (обрана до Європарламенту), натомість Нора Берра увійшла до нього в якості держсекретаря з питань людей похилого віку21. До третього уряду

\footnotetext{
13 Greifeneder I. Analyse du discours sarkozien... P. 125.

14 The Sarkozy Presidency. Breaking the Mould?... P. 141.

15 Сипко Б. Міжрелігійний діалог французьких іудеїв і мусульман на початку XXI ст.: інституційний рівень // Народознавчі зошити. 2018. № 4 (142). С. 836.

16 Сипко Б. Мусульманська спільнота у житті... С. 329.

${ }^{17}$ Le double jeu de Nicolas Sarkozy vis-à-vis des musulmans // Le Nouvel Observateur. 14 mars 2012. URL: https://www.nouvelobs.com/politique/election-presidentielle-2012/20120314.0BS3771/ledouble-jeu-de-nicolas-sarkozy-vis-a-vis-des-musulmans.html

18 Детальніше див.: Berinzon M., Bonhomme L., Marguet L., Rebours L., Sylla M. Les femmes au Sénat // La Revue des droits de l'homme. 2012. № 2; Sineau M. Les femmes et le pouvoir exécutif en France: de l'éxecution... à l'adoublement présidetiel // Recherches féministes. 2010. № 23 (1). P. 81-97.

${ }^{19}$ Décret du 18 mai 2007 relatif à la composition du Gouvernement // JORF. 19 mai 2007. № 115. P. 9714.

${ }^{20}$ Décret du 19 juin 2007 relatif à la composition du Gouvernement // JORF. 19 juin 2007. № 141. P. 10575.

21 Décret du 23 juin 2009 relatif à la composition du Gouvernement // JORF. 24 juin 2009. № 144. P. 10274.
} 
Ф. Фійона (14 листопада 2010 - 12 травня 2012) не увійшли Р. Яде, оскільки стала послом Франції у ЮНЕСКО, та Ф.Амара, яка зневірилася в успішності ініціатив Н. Саркозі. Натомість держсекретарем з питань молоді й асоціацій стала Жанетт Буграб, а Нора Берра очолила держсекретаріат здоров'я22. При цьому, чоловіків, які б мали ілюструвати політику «різноманіття» не було зафіксовано в жодному з урядів Франсуа Фійона, сформованих під егідою Ніколя Саркозі.

У життєвих і політичних стратегіях згаданих політикинь можна виокремити багато спільного. Рашида Даті народилася у передмісті Ліону в багатодітній сім'ї марокканського муляра й алжирської домогосподарки. Попри ісламське віросповідання, дівчинка навчалася у приватному католицькому коледжі. 1999 р. її вперше призначили суддею. 32002 р. Р. Даті була радницею Н. Саркозі (на той час - міністра внутрішніх справ) з питань запобігання правопорушенням, у 2006 р. вступила до партії Об'єднання за народний рух. На посту міністра юстиції Рашида відзначилася непопулярною реформою зі скорочення судів у невеликих населених пунктах 23.

Р. Даті полюбляла наголошувати на тому, що завдяки особистому досвіду прекрасно розуміє проблеми «складних передмість». Так, виступаючи у Бобіньї (столиця департаменту Сена-Сен-Дені) вона наголосила: «Для мене це особисті спогади. Я ніколи не забуду, ні що я тут навчилася, ні що я тут побачила»24. Міністр вважала, що проблема «складних передмість» вимагає комплексного рішення: по-перше, шляхом запровадження окремих відділів по боротьбі проти дискримінацій при французьких судах, слід боротися із нижчими шансами осіб іммігрантського походження отримати омріяну роботу, однак, паралельно із цим необхідно посилити кримінальну відповідальність підлітків, старших 16 років: «Ми повинні захищати не лише підлітка, а й суспільство» 25 . На їі думку, влада повинна сприяти «розмаїтості», якщо та не суперечить французькому законодавству.

Мадам Даті була активною прихильницею міжрелігійного діалогу. Вона не тільки спільно з Фаделою Амарою супроводжувала Ніколя Саркозі у візитах до Великої Паризької мечеті, а й брала участь традиційній щорічній вечері, організованій Представницькою радою єврейських інституцій Франції. Під час одного з таких заходів, 29 жовтня 2008 р. Рашида заявила, що поділяє з єврейською спільнотою несприйняття всіх типів несправедливості, а присутність довкола одного столу представників різних деномінацій $є$ наглядним свідченням «різноманітності», яка стала можливою лише завдяки принципам французької світськості: «у нашій країні можна вірити, а можна й не вірити»26. Цю свободу міністр юстиції використала і в особистій життєвій траєкторії - у січні 2009 р. через п'ять днів після народження доньки Зохри, Р. Даті повернулася до праці, оскільки вважала, що реформи не можуть чекати.

\footnotetext{
22 Décret du 14 novembre 2010 relatif à la composition du Gouvernement // JORF. 16 novembre 2010. № 265. P. 20344.

23 The Sarkozy Presidency. Breaking the Mould?... P. 132.

24 Deplacement de Rachida Dati au TGI de Bobigny. Discours du garde de Sceaux, minister de la Justice. 22 juin 2007. URL: http://www.presse.justice.gouv.fr/discours-10093/archives-des-discours-de-200710239/deplacement-de-rachida-dati-au-tgi-de-bobigny-12723.html

25 Ibid.

26 Déclaration de Mme Rachida Dati, ministre de la justice, sur la diversité, la laïcité, la lutte contre le racisme et l'antisémitisme, sur les relations entre la France et Israël et sur la situation au Moyen Orient, à Montpellier le 29 octobre 2008. URL: https://www.vie-publique.fr/discours/173678-declaration-demme-rachida-dati-ministre-de-la-justice-sur-la-diversit
} 
Бачимо цікаве поєднання - матір-одиначка, яка не називала свого партнера, все ж обрала для дитини мусульманське ім'я.

Рама Яде, як і Рашида Даті, з 2005 р. входила до партії Об’єднання за народний рух, представником якої був і Ніколя Саркозі. Народилася у Дакарі у мусульманській сім'ї, яка переїхала до Франції, коли дівчинці було 11 років. Те, що батько через три роки покинув дружину та чотирьох доньок напризволяще, згодом вплинуло на те, що у політичній діяльності Яде захищатиме, насамперед, жінок ${ }^{27}$. У 1997 р. Рама отримала французьке громадянство, а в 2000 р. і диплом престижного Інституту політичних досліджень Парижа. Попри ісламські корені, Рама Яде не була практикуючою мусульманкою, зокрема у 2005 р. вийшла заміж за історика Жозефа Зімета, іудея за віросповіданням, що суперечить шаріату.

Переплетеність національного республіканського дискурсу та культурної пам'яті яскраво відобразилося 3 листопада 2008 р. у виступі Рами Яде перед ветеранами колоніальних військ у Реймсі. Зокрема, у стенограмі читаємо: «я горда сьогодні бути 3 вами в Реймсі, місті, яке від хрещення Хлодвіга до останньої посвяти короля Франції, було пов'язане з конституюванням Французької Нації»28. I паралельно з цим, держсекретар із закордонних справ згадує про те, що Франція досі у боргу перед ветеранами, які походять з колишніх колоній. Оскільки більше мільйона тубільців служили інтересам Республіки на полі бою, а перемогами на завершальному етапі Другої світової війни Франція завдячувала військам, на 80\% укомплектованим африканцями. Не «забула» Рама Яде підкреслити нерівноправність африканського населення на підконтрольних Франції теренах, закладену ще Луї Фадербом (генерал Наполеона III, який відповідав за колонізацію Сенегалу та формування підрозділів сенегальських стрільців), розстріли повсталих бійців у Тіарое 1 грудня 1944 р., «несправедливу» індексацію пенсій ветеранів (прив'язання до купівельної спроможності конкретної заморської території), проведену 1959 р. ${ }^{29}$ Таким чином, Рама Яде поєднала національний і постколоніальний дискурси.

Призначення Фадели Амари, члена Соціалістичної партії Франції, держсекретарем з питань політики міста, мало проілюструвати прагнення Президента співпрацювати з політичними силами різного спектру. Фадела народилася у передмісті Клермон-Феррана у багатодітній алжирській сім'ї симпатиків Фронту національного визволення Алжиру (політичної організації, яка в 1954-1962 рр. очолювала національно-визвольну боротьбу проти Франції). У 1978 р. 14-річна дівчинка стала свідком того, як її молодший брат загинув під колесами автомобіля, за кермом якого сидів п’яний водій, а поліцейський образив ії матір 30 . Натомість про іншого брата, засу-

\footnotetext{
27 Саме під тиском Рами Яде у другому півріччі 2008 р., коли Франція головувала у Європейському Союзі, пріоритет у правозахисній роботі було надано захисту прав жінок. Див.: Déclaration de Mme Rama Yade, secrétaire d'Etat aux affaires étrangères et aux droits de l'homme, sur le combat pour le droit des femmes, à Paris le 6 mars 2009. URL: https://www.vie-publique.fr/discours/174697declaration-de-mme-rama-yade-secretaire-detat-aux-affaires-etrangeres

28 Déclaration de Mme Rama Yade, secrétaire d'Etat aux affaires étrangères, en hommage aux anciens combattants issus de l'ex-empire colonial français, à Reims le 3 novembre 2008. URL: https://www.viepublique.fr/discours/172837-declaration-de-mme-rama-yade-secretaire-detat-aux-affaires-etrangeres 29 Ibid.

30 Interview de Mme Fadela Amara, secrétaire d'Etat chargée de la politique de la ville, à «El Khabar» le 3 avril 2008, sur son parcours politique, sur l'immigration, et les relations franco-algériennes. URL: https://www.vie-publique.fr/discours/171215-interview-de-mme-fadela-amara-secretaire-detatchargee-de-la-politique
} 
дженого 1984 р. до 16-річного ув’язнення за збройне пограбування ювелірного магазину, Ф. Амара згадувала неохоче.

Як і Р.Даті, Ф.Амара була яскравою представницею покоління берів ${ }^{31}: 1983$ р. брала участь у відомому Марші берів, 1986 р. вступила до правозахисної організації SOS Racisme. «Каталізатором» ï̈ подальшої громадсько-політичної діяльності стало спалення живцем 4 жовтня 2002 р. 18-річної Сохани у погребі передмістя Бельзан у Вітрі-сюр-Сен. 3 того дня Фадела Амара стала речницею пригноблених дівчат і жінок із передмість. 8 березня 2003 р. їй вдалося зібрати на вулицях Парижа понад 30 тис. маніфестанток під прапорами Ni Putes Ni Soumises (Hi Повії, Ні Покірні), про що згодом написала у книзі: «Мені самій не вірилося, що таке можливо»32. Успішна маніфестація заохотила Фаделу у тому ж році створити однойменну організацію та видати книгу-маніфест, основним завданням яких оголошувалася боротьба проти сексизму у передмістях ${ }^{33}$. Основною загрозою для дівчат із «складних передмість» активістки вважали не «батьків», а «старших братів».

Оскільки в той період у Франції тривало громадське обговорення можливості заборони помітних релігійних атрибутів у середніх навчальних закладах, а Ф. Амара активно підтримувала таку заборону, риторика Ni Putes Ni Soumises була схвально сприйнята владою. 14 липня 2003 р. глава нижньої палати Жан-Луї Дебре інавгурував у Національній Асамблеї виставку «Маріанни сьогодення», яка складалася з портретів активісток ${ }^{34}$. А 2004 р. Національна Асамблея відзначила книгу Ф. Амари, як кращий політичний твір рокуз5.

Так розпочалася політична кар'єра Фадели Амари, яку одразу ж запросили до урядових правозахисних організацій (2004 р. до Національної ради із захисту прав людини, 2005 р. до Вищої інстанції у боротьбі проти дискримінацій і за рівність). Свого часу Фадела обурювалася тим, що місцева влада визнала привілейованими співрозмовниками імамів, а це «було жахливо для активістів мого покоління, які протестували проти того, щоби «релігійні діячі» займалися громадськими справами»36. У червні 2007 р., коли Ф. Амарі доручили очолити профільний державний секретаріат з питань міста, вона отримала можливість виправити цю ситуацію.

Оскільки активістка мала реноме опозиціонерки, частина її прихильників не зрозуміла мотивів прийняття цього портфеля, на що вона відповіла: «Я зробила політичний вибір увійти в кабінет Франсуа Фійона. Вирішальний чинник - прагнення Президента Республіки, який мав небувалу сміливість закликати трьох жінок іммігрантського походження до уряду... Через 20 чи 30 років цей політичний акт залишиться в Історії, як важливий маркер еволюції французького суспільства, як розрив із ментальним гетто, табу»37. Але цей перехід, на їі думку, нелегко сприйматиметься суспільством, яке ще не звикло до того, щоби високі пости займали «особи іммігра-

\footnotetext{
31 Термін утворився шляхом арготичного процесу верлану на початку 1980-х рр., і є самоназвою осіб магрибського походження, які народилися у Франції.

32 Amara F. Ni putes ni soumises... P. 5.

33 Garcia M.-C. Des feminismes aux prises avec l'intersectionnalité... P. 112.

34 Benabdessadok Ch. Ni putes ni soumises: de la marche à l'université d'automne // Hommes et migrations. 2004. № 1248. P. 73.

35 Fernando M. Exceptional citizens... P. 380.

36 Amara F. Ni putes ni soumises... P. 74.

37 Déclaration de Mme Fadela Amara, secrétaire d'Etat à la politique de la ville, sur le projet de loi visant à lutter contre les discriminations, Assemblée nationale le 20 février 2009. URL: https://www.viepublique.fr/discours/174332-declaration-de-mme-fadela-amara-secretaire-detat-la-politique-de-la
} 
нтського походження». До того ж, держсекретар попереджала, що вони (Р. Даті, Р. Яде, Ф. Амара) «робитимуть помилки, як і інші міністри, та проведуть успішні реформи, як і інші міністри»38. При читанні стенограм виступів Ф. Амари складається враження, що вона переконувала у тому, що є рівноправною громадянкою не лише слухачів, а й саму себе: «Я, Фадела Амара, донька іммігрантів, виступаю від імені уряду Республіки»39.

Але вже у листопаді-грудні 2008 р. поряд із захопленням діями Ніколя Саркозі простежується критика. Так, 12 листопада 2008 р. Ф. Амара схвально відгукнулася про призначення префектом П’єра Н'Гахана, камерунця за походженням, але іронічно відзначила, що це є реакцією на обрання Барака Обами Президентом Сполучених Штатів Америки, оскільки впродовж попередніх 18 місяців Саркозі не видавав таких розпоряджень ${ }^{40}$. Підтримуючи призначення 17 грудня 2008 р. Язіда Сабега (підприємця алжирського походження) Верховним комісаром з питань різноманіття та рівності шансів, Ф. Амара висловила низку застережень. Зокрема, вона категорично засудила можливість запровадження у Франції т. зв. «позитивної дискримінації», тобто створення пільгових умов для певних категорій населення, а також ведення етнічної статистики. На їі думку, такі пропозиції були нонсенсом, оскільки «Наша Республіка забезпечує рівність для всіх, незалежно від етнічного походження, соціального становища та віросповідання... Не може бути рівності без змішаності, змішаності без світськості, світськості без свободи»41. Однак, держсекретаря з питань політики міста не «почули» і в травні 2009 р. у підготованій Язідом Сабегом програмі дій, що складається з 76 пропозицій, можна знайти низку дискусійних пунктів. Зокрема, зобов'язати дирекцію престижної Національної школи адміністрації, яка готує французьких чиновників, впродовж трьох років 20\% місць віддавати представникам «розмаїтості» (пропозиція № 31), або ж запровадити у середніх навчальних закладах Республіки тему «Франція з численними ідентичностями» (пропозиція № 53) 42. Зауважу, що Я. Сабег втримався на посаді на два роки довше, аніж Фадела Амара.

Цікавим $є$ питання релігійної ідентичності Ф. Амари. В одному з інтерв'ю 3 квітня 2008 р. вона наголосила, що $є$ практикуючою мусульманкою - дотримується п'яти основ ісламу, молиться п'ять разів на добу. Але це її приватна справа. У політиці ж намагається дотримуватися світських позицій і боротися з тими, хто намагається використати релігію в ідеологічних цілях, насамперед, ісламістські асоціації43. Активна прихильниця Закону від 15 березня 2004 р. про помітні релігійні атрибути у се-

\footnotetext{
38 Interview de Mme Fadela Amara, secrétaire d'Etat à la ville, à «France Info» le 19 décembre 2008, sur l'urgence de la visibilité de la diversité sociale dans le pays. URL: https://www.viepublique.fr/discours/173704-interview-de-mme-fadela-amara-secretaire-detat-la-ville-france-i

39 Déclaration de Mme Fadela Amara, secrétaire d'Etat à la politique de la ville, sur le projet de loi visant à lutter contre les discriminations, Assemblée nationale le 20 février 2009...

40 Interview de Mme Fadela Amara, secrétaire d'Etat à la politique de la ville, à «RTL» le 12 novembre 2008, sur la signification de la nomination d'un préfet d'origine camerounaise, M. N'Gahane, et sur la question de la discrimination positive. URL: https://www.vie-publique.fr/discours/172966-interviewde-mme-fadela-amara-secretaire-detat-la-politique-de-la-vi

41 Déclaration de Mme Fadela Amara, secrétaire d'Etat à la ville, sur son opposition à l'introduction du mot diversité dans le préambule de la Constitution, Paris le 18 décembre 2008. URL: https://www.viepublique.fr/discours/173706-declaration-de-mme-fadela-amara-secretaire-detat-la-ville-sur-son-o 42 Sabeg Y. Programme d'action et recommandations pour la diversité et l'égalité des chances. Paris: La documentation Française, 2009. P. 51, 73.

43 Interview de Mme Fadela Amara, secrétaire d'Etat chargée de la politique de la ville, à «El Khabar» le 3 avril 2008...
} 
редніх навчальних закладах, у 2009-2010 р. Ф. Амара підтримала законопроект про заборону закривати обличчя у громадських місцях. Держсекретар наголосила на тому, що бурка - це не вимога ісламу та не релігійна норма, а атрибут одягу, який загрожує республіканським нормам - повазі до жінки та рівності чоловіків і жінок44. Натомість мінарети ніколи не були «політичним проектом», і коли у 2009 р. населення Швейцарії на референдумі проголосувало за заборону їхнього спорудження, це означало дискримінацію мусульман. Але у Франції, на їі думку, «іслам $є$ частиною Республіки та національної ідентичності», і саме завдяки світськості питання заборони мінаретів ніколи не з'явиться тут у порядку денному45.

У листопаді 2010 р. розчарована Фадела Амара відмовилася увійти до третього уряду Ф. Фійона, попри те, що запропонована нею 2007 р. програма розвитку кварталів «Надія для Передмість» ще тривала. У подальшому активістка працювала у Генеральній інспекції соціальних справ, зокрема підготувала низку звітів: про опіку над психічно хворими (2011р.), про супровід учнів-інвалідів (2012 р.), про притулки для підлітків (2013р.), про статус делегованого батьківства (2015 р.), про мобільність робітників (2016 р.), про контроль за процедурами всиновлення (2019р.).

Практикуючою мусульманкою називала себе й Нора Берра, яка 23 червня 2009 р. стала держсекретарем з питань людей похилого віку. Нора народилася в ліонському передмісті у багатодітній сім'ї алжирського стрільця, але зуміла стати доктором медицини. Перебуваючи на посаді, Н. Берра сприяла розвитку паліативної медицини та виступила з ініціативою лікування у Франції поранених у громадянській війні лівійців. Ставши у листопаді 2010 р. держсекретарем здоров'я, Нора продовжила започатковані ініціативи у контексті паліативної медицини, а також виступила з низкою ініціатив. Зокрема, мадам Берра різко засудила можливість легалізації евтаназії у Франції, апелюючи до того, що Закон Леонетті, чинний від квітня 2005 р. гарантує паліативну допомогу, можливість колегіального рішення медиків і рідних хворого про припинення безнадійного лікування, та психологічний супровід близьким. Тому «питання евтаназії в цих умовах - це філософський вибір, вибір людяності - розвивати паліативну допомогу, чи добиватися легального права заподіяти смерть»46.

Восени 2011 р. держсекретар розгорнула масштабну інформаційну кампанію про засоби контрацепції для жінок під гаслами: «Контрацепція - питання не лише здоров'я, а й зрілості суспільства»47 та виступила у Сенаті проти можливості для гомосексуалістів ставати донорами крові, апелюючи до вищого ризику зараження інфекціями, що передаються статевим шляхом. Зауважу, що Н. Берра невипадково активно виступала за контрацепцію, донорство та пересадку органів, оскільки це дозволя-

\footnotetext{
${ }^{44}$ Interview de Mme Fadela Amara, secrétaire d'Etat à la politique de la ville, à France Info le 16 décembre, sur la polémique autour des propos de Nadine Morano sur les jeunes mussulmans, le débat sur l'identité nationale et la sécurité en banlieue. URL: https://www.vie-publique.fr/discours/177815interview-de-mme-fadela-amara-secretaire-detat-la-politique-de-la-vi

45 Interview de Mme Fadela Amara, secrétaire d'Etat à la politique de la ville, à Europe 1 le 1er décembre 2009, sur le vote des Suisses contre la construction de minarets et le bilan 2009 de l'Observatoire national des zones sensibles (ONZUS) de la politique de la ville. URL: https://www.viepublique.fr/discours/177398-interview-de-mme-fadela-amara-secretaire-detat-la-politique-de-la-vi

46 Déclaration de Mme Nora Berra, secrétaire d'Etat à la santé, sur l'euthanasie, Paris le 23 août 2011. URL: https://www.vie-publique.fr/discours/183100-declaration-de-mme-nora-berra-secretaire-detatla-sante-sur-leutha

${ }^{47}$ Déclaration de Mme Nora Berra, secrétaire d'Etat à la santé, sur la contraception, Paris le 26 octobre 2011. URL: https://www.vie-publique.fr/discours/183559-declaration-de-mme-nora-berra-secretairedetat-la-sante-sur-la-cont
} 
ється шаріатом, натомість евтаназія та нетрадиційна орієнтація не толеруються в ісламі. Показово, що мадам Берра не підтримала заборону закривати обличчя у громадських місцях, вважаючи це непотрібною політизацією проблеми, а також різко виступила проти можливості легалізації одностатевих союзів, оскільки «шлюб - це сакральна площина»48. Після обрання в Єлисейський палац Франсуа Олланда Нора Берра стала євродепутатом, а поразку Н. Саркозі пояснювала недостатньою увагою до проблем мусульманського населення: «Визнаймо цю мовчазну та працьовиту більшість, яка заповнює поїзди передмість на світанку, щоби зайнятися роботою, якої інші не хочуть. Визнаймо усіх цих французів, які прагнуть докластися до розвитку нашої Нації... Французькі мусульмани не хочуть особливих прав, а просто поваги»49.

Лакуну, яка утворилася в уряді Ф. Фійона після відставки Ф. Амари та Р. Яде, заповнила Жанетт Буграб, яка охарактеризувала себе так: «я арабського походження, алжирського походження, я француженка, але походження... Я берка, от і все. I донька харкі, і горда нею бути»50. Незважаючи на ці слова, Ж. Буграб аж ніяк не була типовою представницею покоління берів, оскільки їі батько-харкі51 був кавалером Ордену почесного легіону, а дід і дядько вбиті Фронтом національного визволення Алжиру. А сама Жанетт вивчала право в університеті Орлеану та Сорбоні. 32002 р. Ж. Буграб входила до Вищої ради з питань інтеграції й адміністративної ради Інституту арабського світу в Парижі, а в 2010 р. напередодні призначення в уряд очолювала Вищу інстанцію у боротьбі проти дискримінацій і за рівність.

Ставши держсекретарем з питань молоді й асоціацій, Жанетт зверталася і до питання нерівноправності жінок у суспільстві: «Ми живемо в країні, де зарплата чоловіків і жінок відрізняється на 27\%, де $80 \%$ роботи з неповною зайнятістю виконується жінками, пенсія жінки складає 50\%, порівняно з чоловічою, а 80\% домашньої роботи лежить на жінках»52. У цьому ж ключі вона розглядала нікаб - символ виключення жінки-мусульманки з суспільного життя: «це не релігійне питання, а вияв екстремізму»53.

Виваженою була позиція Ж. Буграб щодо слів глави уряду Ф. Фійона про те, що ритуальне вбивство тварин і виготовлення халяльного та кошерного м'яса $\epsilon$ рудиментом. Держсекретар підкреслила, що оскільки у Франції діє свобода слова, то такі питання можуть обговорюватися. Але для неї свято Аїд важливе, оскільки її батько свого часу теж здійснював жертвопринесення баранів. До того ж, якщо дотримува-

\footnotetext{
${ }^{48}$ L'UMP doit reconquérir ses compatriotes musulmans // Le Monde. 26 juillet 2013. URL: https://www.lemonde.fr/idees/article/2013/07/26/l-ump-doit-reconquerir-ses-compatriotesmusulmans_3453247_3232.html

49 Ibid.

50 Interview de Mme Jeannette Bougrab, secrétaire d'Etat à la jeunesse et à la vie associative, à Europe 1 le 4 août 2011, sur la révolte de la jeunesse des pays arabes, les formations en alternance et la discrimination raciale. URL: https://www.vie-publique.fr/discours/183094-interview-de-mme-jeannettebougrab-secretaire-detat-la-jeunesse-et

51 Харкі - допоміжні частини французької армії, які комплектувалися з алжирців, і в роки Алжирської війни 1954-1962 рр. воювали на боці Франції.

52 Interview de Mme Jeannette Bougrab, secrétaire d'Etat à la jeunesse et à la vie associative, à France Inter le 1er juin 2011, sur le sexisme dans la vie politique. URL: https://www.viepublique.fr/discours/182340-interview-de-mme-jeannette-bougrab-secretaire-detat-la-jeunesse-et 53 Interview de Mme Jeannette Bougrab, secrétaire d'Etat à la jeunesse et à la vie associative, à RTL le 11 avril 2011, sur l'entrée en vigueur de la loi interdisant le port du voile intégral dans les lieux publics et l'islam en France. URL: https://www.vie-publique.fr/discours/181947-interview-de-mme-jeannettebougrab-secretaire-detat-la-jeunesse-et
} 
тися санітарних норм, то виготовлення халялю не має становити проблеми, як і маркування цієї продукції, оскільки у Республіці діє практика позначення екологічних товарів ${ }^{54}$.

Таким чином, проведений аналіз дозволяє зробити низку висновків. По-перше, в три кабінети Ф. Фійона почали запрошувати жінок іммігрантського походження ісламського віросповідання, щоб проілюструвати сприяння ґендерній, етнічній і релігійній «різноманітності» влади. По-друге, четверо з п'яти політикинь належали до провладного Об’єднання за народний рух, а залучення Ф. Амари мало свідчити про відкритість до усіх політичних сил. По-третє, четверо з п'яти діячок (окрім Рами Яде) були представниками покоління берів. По-четверте, склався своєрідний консенсус, за якого в одному уряді співпрацювали «діти» харкі (Ж. Буграб і Н. Берра) та трудових іммігрантів, прихильників Фронту національного визволення Алжиру (Ф. Амара), у минулому ідейних ворогів. По-п'яте, і практикуючі (Ф. Амара, Н. Берра) і непрактикуючі (Р. Даті, Р. Яде, Ж. Буграб) мусульманки підтримували принцип світськості та вважали, що релігійна приналежність $є$ приватною справою. Показово, що навіть Н. Берра, яка виступала проти заборони нікабу, не вдягала хіджабу. I, нарешті, такі призначення були чимось принципово новим для республіки, оскільки самі політикині часто наголошували на своєму іммігрантському походженні, апелювали до того, що є такими ж громадянками, як і інші, тобто шукали самоствердження.

У 2011 р. після мюнхенського виступу Девіда Кемерона Ніколя Саркозі заявив, що у Франції політика мультикультуралізму також зазнала краху55. Фактично, глава держави визнав марність власних ініціатив у контексті «різноманіття», оскільки ані до нього, ані після Президенти Республіки не відступали від асиміляційної доктрини. Але попри те, що Ф. Олланд не пропагував концепт «різноманіття», він продовжив політику залучення до уряду жінок іммігрантського походження ісламського віросповідання, найвідоміші з яких Найят Вальо-Белькасем і Міріем ель Хомрі.

\section{REFERENCES}

Benabdessadok, Ch. (2004). Ni putes ni soumises: de la marche à l'université d'automne. Hommes et migrations, 1248, 64-74. DOI: 10.3406/homig.2004.4151 (in French).

Berinzon, M., Bonhomme, L., Marguet, L., Rebours, L. \& Sylla, M. (2012). Les femmes au Sénat. La Revue des droits de l'homme, 2. DOI: https://doi.org/10.4000/revdh.222 (in French).

Fernando, M. (2009). Exceptional citizens: Secular Muslim women and the politics of difference in France. Social Anthropology, 14, 379-392. DOI: 10.1111/j.1469-8676.2009.00081.x

Garcia, M.-C. (2012). Des feminismes aux prises avec l'intersectionnalité: le mouvement Ni Putes Ni Soumises et le Collectif féministe du Mouvement des Indigènes de la République. Recherches féministes, 25 (1), 111-126. DOI: 10.3917/cdge.052.0145 (in French).

Greifeneder, I. (2009). Analyse du discours sarkozien au sujet de l'immigration et de l'identité nationale. Wien: Universitat Wien (in French).

Raymond, G. (Ed.) (2013). The Sarkozy Presidency. Breaking the Mould? London: Palgrave Macmillan.

Sineau, M. (2010). Les femmes et le pouvoir exécutif en France: de l'éxecution... à l'adoublement présidetiel. Recherches féministes, 23 (1), 81-97. DOI: 10.7202/044423ar (in French).

Spina, R. (2012). Enfants de harkis et enfants d'émigrés. Parcours croisés, identités à recoudre. Paris: Éditions Karthala (in French).

Sypko, B. (2018). Mizhrelihiinyi dialoh frantsuzkykh yudeiv i musulman na pochatku XXI st.:

\footnotetext{
${ }^{54}$ Interview de Mme Jeannette Bougrab, secrétaire d'Etat à la jeunesse et à la vie associative à RFI le 8 mars 2012, sur la campagne électorale de l'élection présidentielle d'avril 2012, notamment la polémique sur la viande hallal et la journée des femmes. URL: https://www.vie-publique.fr/discours/184837interview-de-mme-jeannette-bougrab-secretaire-detat-la-jeunesse-et 55 The Sarkozy Presidency. Breaking the Mould?... P. 148-149.
} 
instytutsiinyi riven [Interreligious dialogue between French Jews and Muslims in the early XXI century: institutional level]. Narodoznavchi zoshyty, 4 (142), 832-843 (in Ukrainian).

Sypko, B. (2017) Musulmanska Spilnota u gytti Frantsuzkoi Respubliky (1995-2007) [Muslim community in the life of French Republic (1995-2007)]. Lviv: Ivan Franko National University of Lviv (in Ukrainian).

\section{Bohdana Sypko}

(Ivan Franko National University of Lviv, Lviv, Ukraine)

e-mail: bogdanasypko@gmail.com

ORCID: https://orcid.org/0000-0002-3136-9340

\section{Muslims in the Governments of Francois Fillon}

The composition of three governments under President Nicolas Sarkozy (2007-2012) is analyzed in the paper and the role of Muslims in them is retraced on the basis of the official state press, speeches, interviews, and publicistic works of French politicians. It is found out that F. Fillon's three cabinets began to involve Muslim women of immigrant origin to illustrate the promotion of gender, ethnic and religious diversity of power. It is stated that four out of five politicians belonged to the pro-government Union for the Popular Movement, and the appointing of F. Amara was to show openness to all political forces. Four out of five politicians (except Rama Yade) were the representatives of Beur generation.

It is emphasized that a kind of consensus was formed, in which the children of Harkis (J. Bougrab and N. Berra) and labor immigrants, supporters of the National Liberation Front of Algeria (F. Amara), former ideological enemies, cooperated in one government. It is indicative that both present (F. Amara, N. Berra) and former (R. Dati, R. Yade, J. Bugrab) politicians being Muslims supported the principle of secularism and considered that religious affiliation is a private matter. Even N. Berra, who opposed the ban on the niqab, did not wear the hijab. In addition, despite all the top-level rhetoric, such appointments turned out to be something fundamentally new for the Republic, since politicians themselves often emphasized their immigrant origins, appealing to be the same citizens as others, that is, seeking self-affirmation.

In spite of the fact that in 2011 Nicolas Sarkozy said that in France the policy of multiculturalism had also failed, thus acknowledging the futility of his initiatives in the context of diversity, as neither before nor after his presidency, the Presidents of the Republic even in word never abandoned the assimilation doctrine, some his initiatives were subsequently continued. F. Hollande, although he did not promote the concept of diversity, involved Muslim women of immigrant origin into the government, the best known of which were Najat VallaudBelkacem and Myriam El Khomri.

Keywords: Islam, Muslim politicians, government, France, Nicolas Sarkozy 